\title{
AN INVESTIGATION INTO THE ROLE OF THE QUANTITY SURVEYOR IN THE VALUE MANAGEMENT WORKSHOP PROCESS
}

\begin{abstract}
Purpose: This research investigates the value management workshop process and specifically identifies the roles and responsibilities of the Quantity Surveyor within this. Information accrued is then used to develop a novel template value management workshop that provides a platform for educating future Quantity Surveying and other construction professionals.
\end{abstract}

Research Approach: This research adopts a mixed philosophical epistemological design that utilises interpretivism with elements of postpositivism. Specifically, a cross sectional study of extant literature informs the development of a structured questionnaire that is posed to focus group participants (consisting of experienced industrial practitioners) to secure qualitative feedback and validate the template.

Findings: Research findings reveal that the roles and responsibilities of the Quantity Surveyor in the value management workshop process has hitherto received scant academic attention. Additionally, literature has revealed that available information on workshop content is limited leading to ineffective studies. There has also been a miscommunication among construction practitioners in relation to the Quantity Surveyor's role in the workshop process. Following extensive research, a novel template has been created which identifies the content of each workshop session alongside the roles and responsibilities of the Quantity Surveyor (and other construction professionals) which can be used for educational purposes.

Originality: Literature revealed that scant academic and professional governing body(ies) attention has been paid to the education and training of future generations of Quantity Surveyors involved in value management. Specifically, there is limited applied case study evidence to investigate this phenomena and hence, the workshop curricular presented advances knowledge in this respect and provides a practical template solution.

\section{KEYWORDS}

Value, value management, Quantity Surveyor, workshop,

\section{INTRODUCTION}

"Try not to become a man of success, but a man of value. Look around at how people want to get more out of life than they put in. A man of value will give more than he receives..." (Albert Einstein) 
In any professional field, a commercial project must seek to discover ways in which value can be adopted and utilised to augment outcomes for all involved (Emmitt et al., 2005). This process must be managed through the identification of stakeholder interests and collaboration between these parties to maximise value (Michalski, 2008). Parfitt and Sanvido (1993) noted that whilst managing stakeholder satisfaction is critical to project success, it represents a significant challenge in the construction and civil engineering industry because the various stakeholders involved have differing demands (Shen and Liu, 2007). Therefore, maximising the likelihood of project success requires stakeholders to collaborate and integrate efficiently to increase project team cohesiveness and enhance profitability (Mei-Yung et al., 2003). In a construction context, the Quantity Surveyor is an important member of the value management team who must be introduced to the project at the earliest possible opportunity (Kelly et al., 2014). This is because the Quantity Surveyor is the custodian of cost information and is responsible for analysing the most cost-effective methods for achieving the best possible value for a project (Kelly and Male, 1990).

Despite the pivotal role that Quantity Surveyors perform in the value management team, research reveals (Kelly and Male, 1990) that their introduction in the value management process is often omitted until the later stages of a project development and resigned to the role of cutting costs vis-à-vis forward planning to maximise value. In response, industry has promoted the use of structured workshops to stimulate collaborative working and engender seamless multi-disciplinary working practices and procedures that enhance value (Rangelova and Traykova, 2014). However, the curriculum content of the workshop element (to support the value management process) has become woefully outdated given the advent of disruptive innovative technologies (such as Industry 4.0 and building information modelling (BIM)) that have radically changed working practices within the sector (cf. Edwards et al., 2017; Newman et al., 2020). Typical new innovations include: common data environments for storing project documentation amongst members of the project team (Hosseini et al., 2018); clash detection in design works that impact upon the cost and quantity of materials procured (Pärn et al., 2018); and cyber security needed to mitigate the inherent risks of commercial espionage (Pärn and Edwards, 2019).

Given this contextual backdrop, this research aims to investigate the value management workshop process and create a template curricular content for educating Quantity Surveyors in their changing roles and responsibilities throughout project delivery. In achieving this aim, 
associated objectives realised are to: add to existing literature in relation to content involved in the workshop process; create policy guidance that will serve to stimulate wider polemic debate within professional practice towards the roles and responsibilities of the Quantity Surveyor in workshops; and engender adoption of this research in continued professional development sessions that is to be taught to Quantity Surveying and other construction professionals.

\section{CONCEPT OF VALUE}

Kelly (2007) defines value as: "the quantities of objective or subjective measures which are often interpreted into a financial value as an understandable scale" - which in common parlance is simplistically expressed as value equals function divided by cost. Alternatively, Thomson et al. (2003) defines value as an assessment of the relationship between positive and negative consequences, whereas Mesbah (2014) proffers that value is a balance between cost, time, function and quality. Although varying concepts and definitions of value exist within extant literature, it is important to identify and manage stakeholders' perceptions of value throughout a project cycle as ultimately stakeholder satisfaction is critical in determining project success (Othman et al., 2004). A modern method that can be incorporated into a project to enhance value is to introduce value management (Kelly et al., 2014).

\section{Value Management}

Value management is a process which applies to all project types (Kelly et al., 2014); where the aim is to understand the desired objectives of stakeholders and assess the resources needed to accomplish the established goal (Mei-Yung et al., 2002). Value management concentrates on reviewing and defining methods employed from the early stages of a project to ensure that appropriate strategies have been considered to fulfil stakeholders' demands (Petrash, 1996). Conflicting opinions are apparent regarding how value management can be interpreted within a project (Thyssen et al., 2011). Thus, to achieve the best value for all stakeholders involved (Mei-Yung et al., 2003), contrasting priorities between the project parties must be first resolved (Othman et al., 2004). Nevertheless, and despite these initial difficulties associated with achieving shared value integration, value management is an imperative part of a project's success because it establishes a process for maximising project outcomes and success (Michalski, 2008). By establishing key stakeholders' aims and objectives at the project's early stages, the value management process allows a considerative approach to be undertaken which helps achieve a greater understanding of individual team member's needs. It also reviews potential risk factors that may jeopardise project success such as changes in the project 
programme and any anomalies within the project brief or specifications (Mei-Yung et al., 2003). By identifying potential project risks early on, a review and discussion can be held (amongst project team members) regarding the best possible solutions to moving the project forward from a range of potential alternatives (Thyssen et al., 2011). This cyclical process of review and informed decision making (Oki and Aigbavboa, 2017) mitigates the likelihood of future project inefficiencies (Shen and Cheng, 2001) but also provides the foundations for developing an effective team by collectively agreeing a suitable strategy (Michalski, 2008).

Value management ideally focuses on working collaboratively and engaging as a project team (Kelly et al., 2014). Collaboration between the project team is important because it leads to enhanced cohesiveness and it means that all team members have had a chance to offer their input before any decisions are derived (Othman et al., 2004). The lead figure in the value management process is usually the internal project manager who is appointed to lead the project, however, an external value management lead is also a viable option (Constructing Excellence, 2004). The value management leader plays an important role in understanding matters discussed in workshops and meetings held (Thyssen et al., 2011) in order to: i) distribute information and knowledge assimilated to the relevant parties; ii) motivate the project team to meet the project's objectives; iii) demonstrate innovation and generate pragmatic solutions to potential project risks; and iv) ultimately lead the project team forward to a successful project conclusion (Poudyal, 2013). The concomitant benefits of value management adoption are myriad (Locke, 1994) and include: i) obtaining maximum project efficiency (Emmitt et al., 2005); ii) considering alternative design options (Oki and Aigbavboa, 2017); iii) ensuring all project members have clear roles (Poudyal, 2013); iv) enhancing stakeholder engagement (Shen and Liu, 2007); v) ensuring that there is a clear project brief (Mei-Yung et al., 2003); vi) identifying potential project risks (Abidin and Pasquire, 2005); vii) increasing efficiency of individuals working in a multi-disciplinary team (Kelly, 2007); and viii) improving the project team relationships (Rangelova and Traykova, 2014). The nature of the project and the project's aims ultimately determine how the value management process can be implemented (Norton and McElligott 1995). However, regardless of implementation strategy, a number of potential project scenarios that could benefit from adopting the value management process are extensive and include: i) state-of-the-art projects where the introduction of an expert value management specialist can offer assistance in managing one off projects (Rangelova and Traykova, 2014); ii) projects that require acceleration to completion due to client demand (Kelly et al., 2014); and iii) projects with a budget that cannot overrun - such as 
critical infrastructure assets (e.g. power networks or transportation) (Kumar and Van Dissel, 1996).

\section{Defining Value Management vs Value Engineering}

Value management has been successfully applied in several countries around the world (Norton and McElligott, 1995) and has particularly seen a substantial growth in use over the past two decades (Kelly et al., 2014). The Latham 1994 (Latham, 1994) and Egan (Egan, 1998) reports stimulated the wider adoption of value management in the construction civil engineering sector due to its perception as good practice and encouraging collaborative working. Aligned to value management is the concept of value engineering which focuses on reducing project costs (Kelly and Male, 1990) - which in contrast to value management, reviews the overall process of analysing methods to maximise value related to the project (Kelly et al., 2014). So although the terms tend to be used interchangeably (cf. RICS, 2017), there is a distinction between them (refer to Table 1)

<Insert Table 1 about here>

The Royal Institution of Chartered Surveyors (RICS) note that a key difference between the value management and value engineering processes is that the value management process should be positive as it seeks to achieve an optimum balance between time, cost and quality through an integrated multi-discipline approach (ibid). This contrasts to value engineering which can be viewed as a negative cost eliminating process (Kelly and Male, 1990) and notably, because the Quantity Surveyor is often introduced later in the process, there is less time to consider viable alternatives to building elements that may be causing problems. Additionally, because cost is a decisive factor on determining the overall project success (Shen and Liu, 2007), the Quantity Surveyor is often placed in the unenviable role of attempting to make good other decisions that were made earlier in the project's conception or design phase; such runs contrary to the idea of collaborative working in the value management process.

\section{Defining the Quantity Surveyor?}

The Quantity Surveyor performs a fundamental function to any construction or civil engineering project, with this professional role first introduced by the RICS in 1864 (Seeley and Winfield, 1999), (Seeley, 1984). Quantity Surveyors provide advice on stakeholder's requirements and are held in high regard by project stakeholders as they add value to the cost 
management of a development (Olanrewajua and Anahve, 2015). Cost management advice offered by the Quantity Surveyor during the feasibility, design and construction stages of a project is important to all stakeholders involved in a development (Nkado and Meyer, 2001). Regular communication between the design team members and the Quantity Surveyor is imperative (Maarouf and Habib, 2011) in order to produce accurately measured order of cost estimates and formal elemental cost plans pertaining to project cost (Mbachu, 2015). As the project progresses into the construction/post contract stage, the role of the Quantity Surveyor is to value employer's change orders - also known as variations i.e. design changes which impact upon overall project cost (Kirkham, 2007). Further duties can include assistance with claims management, producing life cycle cost estimates and agreeing the final account for the project (Ashworth, 2014). Refer to Figure 1 which presents the roles of a Quantity Surveyor through the different stages of the RIBA Plan of Work 2013.

$<$ Insert Figure 1 about here>

\section{The role of the Quantity Surveyor in the Value Management process}

Cost is always a focal point in any project (Mbachu, 2015) and is an important part of the value management process (Rangelova and Traykova, 2014). Kelly and Male (2006) noted that in the absence of a cost expert in the value management exercise, the outcome will not be a financial success. Due to this, Oki (2010) proffers that this role is arguably more significant than other project members in the value management process. The Quantity Surveyor should be introduced into the value management process at the earliest possible opportunity to ensure that there is sufficient time to review project costs (Kelly and Male, 1990). Moreover, they should ensure that a range of project related alternatives have been thoroughly reviewed and discussed before collectively agreeing a strategy (to achieve best value on project costs) in the multidisciplinary team (Stewart, 2010). Interestingly, despite its prominence, value management is not listed in the areas of competencies required by the RICS (as a governing body) for Quantity Surveyors when sitting their Assessment of Professional Competence (Oki and Ogunsemi, 2013). Rather, value management remains an optional competency even though the Quantity Surveyor's participation is essential for gaining maximum cost efficiency which can overall maximise the value of the project (Emmitt et al., 2005). 


\section{IMPLEMENTATION OF VALUE MANAGEMENT THROUGH WORKSHOPS}

Although the process of value management can be incorporated into a project in various ways, a structured workshop session(s) remains a ubiquitous approach (Thyssen et al., 2011). Workshops are set up by the value management leader and can involve all members of the project team including key stakeholders (such as the architect, client and contractor). Workshops are an efficient way of embedding the process into a project because they encourage all members of the project team to partake in reciprocal dependency (cf. Kumar and Van Dissel, 1996). Structured workshops allow the project team to comprehend the progressive development of the value management study (Stewart, 2010). The curricular design of a traditional workshop consists of six iterative (yet inextricably linked) themes; where detail within each theme is dependent on the scale and complexity of the project under development (Norton and McElligott, 1995). It is important to continue workshops if necessary, throughout the project to ensure that: project aims are regularly reviewed and all members are confident in realising how the stakeholder's needs are to be achieved; and maintain regular communication between project team members to ensure that a cohesive community of practice is achieved (Kelly, 2007). Table 2 provides guidance on the six themes that are presented within a traditional workshop, these are: i) the information workshop; ii) the creativity workshop; iii) the evaluative workshop; iv) the development workshop; v) the presentation workshop; and vi) the feedback workshop. In contrast, the RIBA plan of work 2020 links stages 0-7 (i.e. strategic definition to a building in-use) of a project development to value management workshops but these are only linked to the first four stages viz: stage 0 strategic definition - value management workshop (client led); stage 1 preparation and briefing - value management workshop (client and design team); stage 2 concept design - value management workshop (design led); Stage 3 spatial coordination - value management workshop (design-led, contractor if appointed and value engineering study (design team or discipline-led and contractor if appointed)); and stage 4 technical design - value management workshop (designled, contractor if appointed and value engineering study (design team or discipline-led and contractor if appointed)). Two important matters are apparent. First, the disparity that exists between the RIBA plan of work and literature on the number and content of workshops used; and second, the RIBA plan does not detail the number of workshops needed at each stage and/or the content of such.

<Insert Table 2 about here> 


\section{BARRIERS TO AN EFFECTIVE VALUE MANAGEMENT STUDY}

Extant literature has noted several barriers that curtail an effective value management process on construction projects. These include: the lack of trained value managers and facilitators; the late introduction of the Quantity Surveyor when implementing a study; and the dated workshop process alongside the lack of participation from disciplines in workshop studies.

- $\quad$ Lack of trained Value Managers and Facilitators. Male and Kelly (2008) stated that the value manager must have the ability to "understand a value problem, design, structure and implement a process to bring value systems together and introduce improvements." In addition, Mesbah (2014) noted that in order to achieve the aims and objectives of the value management process, the facilitator must ensure that the team remain focused on the project's specific objectives in order to fulfil a successful workshop. However, a study by Oke (2010) reports a lack of trained and knowledgeable value managers who are unable to direct the team to achieving predetermined set objectives.

- $\quad$ Late introduction of the Quantity Surveyor in the value management study. The attention to cost in the value management process has meant that the idea of collaborating as a team (in order to maximise a project's value holistically) is lost (Mei-Yung et al., 2002; Kelly et al., 2014) and it often falls upon the Quantity Surveyor to arrive at methods to make the project viable. Stuart and Anita (2007) proffer that Quantity Surveyor's involvement is limited to the later stages of the project lifecycle thus creating a false perception that clients employ them as 'after-the-event cost cutters'. After-the-event cost cutting activities automatically skips the value management process and turns the emphasis to achieving the lowest price rather than best value (Olawumi et al,. 2016).

- $\quad$ The dated workshop process alongside the lack of participation in the studies. The workshop process is aimed at being a structured, integrated and collaborative method of implementing value management on a project (Ellis, 2004) however, this approach has become less apparent of recent times. Male et al. (1999) noted that the workshop approach has become a routine 'tick box' exercise whereby studies are condensed to achieve quicker results - an intension that contradicts the foundations and structure delineated for achieving an effective study (Fong, 2004). Furthermore, Kelly et al. (2004) noted that in order to achieve an effective workshop study, there must be participation from all members of the multi-disciplinary team. Olawumi et al. (2016) noted that 
participants have become passive in their behaviour within workshops which results in an ineffective study and loss of collaboration between parties.

In summary, extant literature illustrates a lack of information in both academic journals and professional practice documents (published by reputable bodies such as the RICS) that define the various roles and responsibilities of the contemporary Quantity Surveyor in the value management workshop process. This lack of professional guidance could be a key reason as to why the workshop approach has become dated and, in many ways, largely redundant (Ellis, 2004). Therefore, further research and investigation is needed to create a structured hybrid template of information that can be used to educate the Quantity Surveyor about the stages of the value management workshop process and particularly their specific roles and responsibilities in the workshops.

\section{RESEARCH APPROACH}

This paper adopts a mixed philosophical research approach using an interpretivist epistemological design (with aspects of postpositivism) to analyse extant literature as a step to developing a robust scientific data collection instrument (Roberts et al., 2019). Goldkuhl (2012) said that adopting an interpretivist approach allows for subjective meanings to be acknowledged, reconstructed and built upon for future development in theorizing. In addition, Denizin and Lincoln (2011) noted that an interpretivist research approach allows for a range of methods utilised to develop an understanding of the problem domain. By adopting an interpretivist approach, phenomena will be investigated in a natural setting (Tuli, 2010) whereby the interviewees thoughts, values (i.e. axiology) and perspectives can be probed (Wellington and Szczerbinski, 2007). However, interpretivism does have several limitations (Pham, 2018), for example: gaps in verifying the validity of results due to the research not being generalised (Cohen et al., 2011); and adopting the ontological view of interpretivism tends to be subjective which can lead to skewed results and social bias (Mack, 2010). An inductive mixed method research approach, specifically with elements of grounded theory will be adopted to allow synthesis of the research problem domain and generate valid and reliable findings (Soiferman, 2010).

\section{Methods and Analysis}

The methods used to explore the problem domain will include a questionnaire data collection instrument (refer to Appendix A) and a focus group study. All participants were assured that 
information collated will remain strictly confidential and that no personal data will be disclosed nor disseminated to any third party willingly or otherwise (Oliver, 2010). Moreover, all data will be destroyed at the end of the study and participants have the right to pull out at any time of the process (Fisher et al., 2018). The questionnaire aims to collect primary data from participants in the quantity surveying construction discipline who vary in age and experience. The objective is to collate relevant information on curricula development from participants who have had some form of involvement in the value management workshop process during their working experience. The responses were analysed through a software tool called Voyant Tools which is effective in assessing the trends and frequencies between responses from the participants to the questionnaire. This is demonstrated by producing various adjectives as a result of the questionnaire responses, with the size of the font that relates to the adjective reflecting the frequency of occurrence regarding the various participant responses.

The information collected was then used in a focus group session whereby participants were invited to comment upon whether the content that has been created from questionnaire responses and Voyant Tools offers credible knowledge that can be used to create the 'Hybrid Workshop' template. The Hybrid Workshop template was presented in a table format with the aim of it being used for continued professional development. Participants selected for the focus group session are Quantity Surveyors at director level, as their experience can prove valuable in collating the correct data. Focus groups have provided a unique platform to gain credible knowledge for a particular subject and have proven to be an effective way of gathering research (Harrison et al., 2017). The participating organisation was a large construction project management consultancy who offer services in quantity surveying, building surveying and health and safety, and are based in the West Midlands, UK. The consultancy offer a range of services such as commercial, education, infrastructure and industrial, have an annual turnover of circa thirty million pounds and employ over 120 employees. Primary data in the form of largely qualitative responses were then analysed using open source content analysis software (Voyant Tools). The ambition being to locate trends or phrases within a large corpus and help to contextualize frequencies in word usage from the response of the participants (Felix et al., 2018). In doing so, a much clearer picture of viewpoints and opinions can be obtained.

<Insert Appendix A about here> 


\section{RESULTS}

In total, 45 responses were received from participating professionals. The participants varied in age, job title and experience in order to offer a range of responses from varied demographics who work within the industry. Job titles and experience were separated out into three categories; intermediate, who offered 5-9 years' experience, Senior, who offered 10-15 years' experience and director level who offered 15+ years' experience. Additionally, all the participants were between the ages of 21 and 65. In order to offer an impartial spread of results from the varied demographic, 15 responses each were received from the three categories as described above. The questionnaire responses acknowledged a frequent response from all levels relating to the length of a typical workshop which ranged between 2-4 hours. From gathering this information it can be seen that the participants are agreement with one another. Those professionals that agreed to participate in the focus groups were chosen from those that answered positively in this question. Their expertise was valuable in understanding the needs for 'The Hybrid Workshop'.

The responses from participants varied when asked about what content and what should be covered as a minimum in the six separate workshops. Results showed that several participants who were at the intermediate level of experience responded with limited detail in comparison to the senior and director level participants. There were several reasons for this. Firstly, the majority of participants who are at intermediate level have less experience within the construction industry and were generally aged between 21 and 35, which limited their ability to comment in vast detail relating to the content of the six separate workshops. Additionally, it was visible in the responses from participants at the intermediate level that the detail within their responses was related to what sector they worked in within the company. For example, participants who worked within the commercial services sector and work on projects involving new build office and residential schemes offered responses in greater detail compared to those who worked within the infrastructure and highways team and work on projects such as major motorway repairs. A reason for this was due to the nature of the work within the sector. Work within the commercial services sector generally offers more opportunities for value management workshops to take place therefore participants have greater exposure to the workshop process in comparison to those who are in the Infrastructure and Highways team.

This contrasted to participants who were at senior and director levels who were able to offer responses in greater detail in relation to content within the six different workshops. This was to 
be expected as participants with more experience within the construction industry would tend to have a greater chance of having involvement within the value management workshop process and were aged between 30 and 65. The responses also showed a wide spread of knowledge across different sectors of the industry and organisation which was not visible in the responses from participants at the intermediate level. With more experience comes the opportunity to move between sectors therefore offer experience in more than one field. This was reflected in their knowledge from experiences of workshops, and was clearly visible in responses. However, there were also discrepancies between responses from senior and director participants. The majority of the responses from directors tended to be in more detail, probably as a result of their wealth of experience, with the most detailed offered in relation to the 'The Information Workshop'. One explanation for this is that directors will usually attend this workshop to meet the client/stakeholder for the first time to understand their personalities and key objectivities before handing over to intermediate/senior members for future workshops and work on the day to day activities of the project.

The data gathered from participants at intermediate, senior and director levels in the questionnaire responses could then be analysed utilising Voyant Tools. Refer to Figure 2 to see an example of the Voyant Tools analysis tool in relation to the question: 'As a minimum, what content should be covered in 'The Information Workshop'. The tool analyses the data inputted from questionnaire responses to identify the adjectives utilised within a corpus and the frequency within the participant responses. The analysis software identified thirteen unique words that arose frequently, including adjectives such as 'review' which appeared eighteen times, and 'brief' and 'objectives' both appearing twelve times. This suggests that participants involved in the questionnaire felt strongly that it is important to review the brief and review objectives in 'The Information Workshop. Additionally, these responses were evidence of importance to explore these aspects further into the focus group session where further analysis and validation of the contents of the workshop were validated further by construction practitioners. This process of reviewing questionnaire responses and analysing the data through Voyant Tools to assess relevant themes and trends was carried out for each of the questions to determine what content should be covered within the separate workshops.

<Insert Figure 2 about here> 
The questionnaire responses from participants offered greater detail holistically when responding to what the roles and responsibilities of the Quantity Surveyor are within the six separate workshops than when compared to the questions relating to what content should be covered within those same workshops. A key reason for this was due to the previous questions whereby participants understood what content would be in the different workshops and therefore were able to offer general responses relating to the roles and responsibilities of the Quantity Surveyor. Furthermore, as participants were specifically talking about the role of the Quantity Surveyor, they had confidence in expressing what the typical roles and responsibilities include.

That said, similar to the other set of results, it was visible from the participants responses within the Intermediate level of experience that they were not able to offer the depth of knowledge in their answers compared to those who were at senior and director levels of experience. Specifically, when commenting on 'The roles and responsibilities of the Quantity Surveyor in the Feedback workshop', it was emphasised by the length of their responses which ranged from a couple of words to three or four sentences at most. This contrasted to the senior and director level responses which offered lengthy detail, and some were as long as two paragraphs. However, this was to be expected with the less experienced participants as they could only comment on their involvement and experience within workshops. Additionally, the results also showed similar trends to the other set of results whereby the responses were differentiated due to the specific sector that the individual works in and some participants have not had the exposure to the whole workshop process in their working career whilst others may have been involved in the process in previous year therefore lack up to date knowledge on the specifics.

Questionnaire responses relating to 'The roles and responsibilities of the Quantity Surveyor in the Information Workshop' in particular offered the most similarity between participants across all levels. A key factor for this is the importance of the workshop, this was said by all of the respondents. As this is the first workshop, participants highlighted the importance of this workshop to set up the project with all of the value management team getting together to discuss the project holistically for the first time. A prevalent response which was seen in all 45 responses related to "identifying key drivers" and "key objectives in relation to costs". Seeing as these responses were frequent across all levels of age and experience, it creates cogent data that can be taken forward into the focus group session to understand why and develop further. 
Like analysing the data above relating to 'As a minimum, what content should be covered in 'The Information Workshop, ', it was feasible again to use the data gathered from participants at intermediate, senior and director levels in the questionnaire responses to replicate the same process in Voyant Tools. Refer to Figure 3 to see an example of the Voyant Tools analysis tool in relation to the question of 'From experience, what are the roles and responsibilities of the Quantity Surveyor in the 'Evaluative Workshop'? The analysis tool identified fifteen unique words based on the frequency in which they came up. Two of the frequent words that came up were 'advice' appearing fifty times and 'solutions' appearing thirty-eight times. This would suggest that these are two common factors in the Evaluative Workshop where the Quantity Surveyor would offer cost advice depending on the current financial situation and come forward with solutions to potentially steer the cost to where it is required. Due to the frequency and trend of the responses, this was then used as a discussion point for the focus group.

<Insert Figure 3 about here>

\section{Focus Group}

The data sought from questionnaire responses and Voyant Tools was carried forward into the focus group session. The session lasted for three hours where the participants discussed, analysed and requirements contents of workshops. The aim of the focus group was to validate the data that had been collated from the questionnaire phase. After reviewing the results found from the questionnaire in detail, minor amendments were made where necessary, the practitioners within the focus group agreed on the requirements for the "The Hybrid Workshop'. This was presented in a simple bullet point table format. The practitioners were also able to give a brief description about the six separate workshops which included how long the workshops would last in order to help future users with their understanding of what the workshops entail. Refer to Table 3 to review 'The Hybrid Workshop'.

<Insert Table 3 about here>

\section{DISCUSSION}

This paper has brought together key information that could contribute to the success of value management workshops and the role that Quantity Surveying professionals play in them. The Hybrid Workshop agenda developed as part of this research provides a means for a more productive workshop as well as providing details to educate future Quantity Surveyors in 
continued professional development activities. As this research has been informed by industry experts in the development of the criteria, it is envisaged that uptake from construction professionals will be quick and they will be able to make use of the research findings.

As Quantity Surveyors play an imperative role in the value management team and as well as the overall construction team in determining project success, other disciplines in the value management team can use the research here to educate themselves about how the Quantity Surveyor affects the value management team. This guidance can be beneficial for key project Stakeholders to plan, prepare and understand the role of the Quantity Surveyor for future projects which in turn, could potentially lead to an increased success in future value management workshops. Cumulatively, the findings provide a platform of criteria available to construction professionals that was not apparent prior to the research conducted.

\section{Theoretical contributions to the work}

Pertinent literature revealed that the phenomena under investigation has not been sufficiently explored, with a lack of guidance from governing bodies like the RICS also seen has meant confusion and a lack of clarity among Quantity Surveying professionals in value management workshop sessions. The outcome of this research should be considered a utility for practitioners providing accessible information to be used within the construction sector, but it also with potential to be built upon and developed further in the future. Additionally, this research contributes to existing literature in relation to the content involved in the six separate workshops. Scant literature acknowledged the 'Traditional Workshop' approach (refer to Table 2) offering limited information that was available to construction professionals. This research has developed a set of validated criteria (Table 3) that now provides a greater improvement to the 'Traditional Workshop' in value management that is user friendly and could become an important tool for educating future users of the value management workshop process.

\section{Limitations to the research}

The research that has been carried out does offer limitations. Firstly, the participants involved in the questionnaire were taken from only one private sector organisation. To strengthen this research, the questionnaire could have been opened up to other private sector companies who have been involved in the value management workshop process, this would offer different knowledge and experiences in order to strengthen the research investigation. Furthermore, the company chosen to gather the primary research from was private sector based only therefore 
this was another factor that limited questionnaire responses. The research questionnaire could have been opened up to public sector workers who again, could have potentially offered valuable experience to increase the credibility of the research.

Moreover, in order to gain an increase in questionnaire responses, the questionnaire could have been opened up to an online network through apps like LinkedIn and Facebook and carried out through an online portal such as Survey Monkey. By doing this, it gives a greater chance of increasing the number of responses using an online network and could lead to a wider range of knowledge and feedback from a variety of networks. However, online networks like these can also reveal unreliable knowledge as participants taking questionnaires can be from any profession or background and may offer little or no knowledge about the subject under investigation. This can lead to skewed results and findings as the data is not dependable for practical use among construction professionals.

Additionally, the focus group session that took place offered limitations that could be improved in future research activities. Firstly, there were five participants who took part in the session. This was an acceptable number to have in a focus group as you do not want to over crowd the session as there is a chance that the particular focus can be easily navigated in the wrong direction. However, the number could have been increased by two or three additional participants who could contribute to the research further with their practical expertise.

Also, the participants chosen to validate the data were at the director level only, with fifteen or more years' experience within the industry. These participants were chosen due to their wealth of experience in the value management process and therefore could identify credible knowledge that can be used to educate Quantity Surveyors in the value management workshop process in the future.

However, research suggested that some of these participants are not actively involved in the workshop sessions following 'The Information Workshop as their role is more significant within the day to day running of the company and it is likely to be professionals at Intermediate and Senior levels who are actively involved in the holistic workshop process. Therefore, for future research, members at these levels who are actively involved in the workshop sessions throughout a project could also be involved in the focus group session. They may be less experienced in relation to number of years in the industry, their knowledge and understanding 
of the current value management process could be combined with the experience of director level Quantity Surveyor's that could, together, create an improvement to the research findings.

\section{Future work}

To an extent, this research has opened up various opportunities to cover the topic of value management in greater detail, and has now given the opportunity for future researchers to explore topics that are similar in nature to this one. Firstly, this research was specifically directed towards the role of the Quantity Surveyor in the value management workshop process, and it is apparent from this research that for the workshop process to be successful, there needs to be an integrated and collaborative approach between project team members. Therefore, there is an opportunity to explore the roles and responsibilities of other construction disciplines who are a part of the value management team. Potential future research could be directed towards the architect's, project managers, development managers, or the client/stakeholder's role in the value management workshop process whereby similar templates of information can be created to educate the particular construction discipline under investigation in continued professional development.

If the future research is executed (see above) there is an opportunity to combine and consolidate the literature in order to create a novel 'Value Management guide'. This would explain the overall value management workshop processes including the roles and responsibilities of all disciplines involved. This information could be beneficial to any new and existing members of the value management workshop process. The aim is to educate and enhance their current knowledge on the holistic workshop process. Furthermore, scant literature has revealed that the current workshop process is generally face to face with other team members. However, there could be an opportunity to explore the workshops to be used through an online software that can hold group conference and video calls. By exploring this option, it could potentially mitigate the of loss of unproductive time that occurs as the current workshop process may take up to a day of the team's time with travel and other associated elements. By moving the sessions to an online platform, it could allow the team to use the current time that is currently lost productively, and they wouldn't have to travel to one associated destination.

\section{CONCLUSION}

The value management workshop process can be a fundamental part of a project when implemented successfully. However, in recent times, this process has not been carried out 
efficiently which ultimately leads to ineffective outcomes. A central reason for this correlates directly to the confusion among value management team members of the roles and responsibilities of the Quantity Surveyor, including the Quantity Surveyor themselves, who is arguably one of the most important members of a value management team. This also stems from a lack of guidance from governing bodies like the RICS about the role of the quantity surveyor in the value management process.

In construction, the cost of a project is plausibly a deciding factor whether a project is seen to be successful or not, and it is often down to the Quantity Surveyor to increase the chances of making the project viable. For this reason, the Quantity Surveyor can often become a scapegoat in workshop sessions and become an easy target to blame when the project is not going as originally planned. Additionally, scant literature and research has revealed that the late introduction of the Quantity Surveyor is also a contribution to failed workshop studies as they have been drafted in to the workshop sessions at a later date to essentially 'value engineer' the costs to make the project feasible. Consequently, literature also reveals that other disciplines in the value management team believe that the role of the Quantity Surveyor in workshop sessions is to be used to 'cut costs' when necessary which is a misconception. However, the Quantity Surveyor cannot justify this position due to a lack of guidance available to establish their roles and responsibilities within a workshop. Scant literature has also revealed that there is a lack of information relating to the content involved in each of the separate workshops which again, is contributing to wasteful workshop sessions. There is also a lack of detailed advice available for educational purposes.

The findings of this research have augmented existing literature which was weak and ambiguous in relation to the content of the workshop process. The outcomes from this research has been created to be used in continued professional development activities, as well as future construction value management workshop practitioners. This work supplements existing research by adding fresh knowledge and detail relating to the content involved in the separate workshops. Moreover, the findings of this research can be used as an educational tool, not only for Quantity Surveyors but for other construction practitioners to understand the roles and responsibilities of the Quantity Surveyors in the value management workshop process. This is valuable for educational purposes and was information that was not readily available prior to this research being carried out. Furthermore, the findings of this research can be used as a protection tool for Quantity Surveyors, as a clear structure for people to understand their roles 
and responsibilities within a value management workshop is proposed, and effectively diminishes the idea that their role is strictly to 'cut costs'. Ultimately, the findings of this research are to be used as a catalyst that can encourage future researchers to develop other areas of the value management workshop process with the aim of revolutionising value management in the construction industry. 


\section{REFERENCES}

Abebooks.com. (2019). 0333719727 - Building Quantities Explained Building and Surveying Series by Ivor H Seeley; Roger Winfield - AbeBooks. [online] Available at: https://www.abebooks.com/book-search/isbn/0333719727/ [Accessed 2 Dec. 2019].

Aghimien, D., Oke, A. and Aigbavboa, C. (2018). Barriers to the adoption of value management in developing countries. Engineering, Construction and Architectural Management, 25(7), pp.818-834.

Anon, (2019). [online] Available at: https://www.academia.edu/8906242/Quantity_surveying_role_in_Construction_Projects_ -a_comparison_of_roles_in_Sweden_and_the_UK_Examensarbete_VT_2011 [Accessed 2 Dec. 2019].

Anon, (2019). [online] Available at:

https://www.researchgate.net/profile/Jasper_Mbachu/publication/306235887_Quantity_s urveyor\%27s_role_in_the_delivery_of_construction_projects_A_review/links/57b410fb0 8aeac3177851812/Quantity-surveyors-role-in-the-delivery-of-construction-projects-Areview.pdf [Accessed 2 Dec. 2019].

Anon, (2019). [online] Available at:

https://www.researchgate.net/publication/315029674_Comparing_Qualitative_and_Quan titative_Approaches [Accessed 12 Dec. 2019].

Anon, (2019). [online] Available at:

https://www.researchgate.net/publication/227091950_Qualitative_Research_and_Public_ Policy_The_Challenges_of_Relevance_and_Trustworthiness [Accessed 12 Dec. 2019].

Architecture.com. (2019). Royal Institute of British Architects. [online] Available at: https://www.architecture.com/ [Accessed 2 Dec. 2019].

Bokus.com. (2019). Value Optimization for Project and Performance Management av Robert B Stewart (Bok). [online] Available at: https://www.bokus.com/bok/9780470551141/valueoptimization-for-project-and-performance-management/ [Accessed 2 Dec. 2019].

Constructing Excellence. (2019). Constructing the Team (The Latham Report). [online] Available at: http://constructingexcellence.org.uk/resources/constructing-the-team-thelatham-report/ [Accessed 2 Dec. 2019].

Consulting, T. (2019). The Egan Report. [online] Twcconsulting.com. Available at: https://www.twcconsulting.com/report/ [Accessed 2 Dec. 2019].

Coulson-Thomas, C. (2005). Encouraging partnering and collaboration. Industrial and Commercial Training, 37(4), pp.179-184. 
Cowan, J. (2011). Research methods in education - By Louis Cohen et al. British Journal of Educational Technology, 42(5), pp. E110-E110.

Denzin, N. and Lincoln, Y. (2011). The SAGE handbook of qualitative research.

Edwards, D. J., Pärn, E. A., Love, P. E. D. and El-Gohary, H. (2017) Machinery, manumission and economic machinations. Journal of Business Research, 70, pp. 391-394. DOI: https://doi.org/10.1016/i.jbusres.2016.08.012

Ellis, R., Wood, G. and Keel, D. (2005). Value management practices of leading UK cost consultants. Construction Management and Economics, 23(5), pp.483-493.

Felix, C., Franconeri, S. and Bertini, E. (2018). Taking Word Clouds Apart: An Empirical Investigation of the Design Space for Keyword Summaries. IEEE Transactions on Visualization and Computer Graphics, 24(1), pp.657-666.

Fisher, L., Edwards, D., Pärn, E. and Aigbavboa, C. (2018). Building design for people with dementia: a case study of a UK care home. Facilities, 36(7/8), pp.349-368.

Fong, P. (2004). A critical appraisal of recent advances and future directions in value management. European Journal of Engineering Education, 29(3), pp.377-388.

Goldkuhl, G. (2012). Pragmatism vs interpretivism in qualitative information systems research. European Journal of Information Systems, 21(2), pp.135-146.

Harrison, H., Birks, M., Franklin, R. and Mills, J. (2017). Case Study Research: Foundations and Methodological Orientations.

Hosseini, M. R., Pärn, E. A., Edwards, D. J., Papadonikolaki, E. and Oraee, M. (2018) Roadmap to mature BIM use in Australian SMEs: a competitive dynamics perspective. Journal of Management in Engineering, 34(5), pp. DOI: https://doi.org/10.1061/(ASCE)ME.1943-5479.0000636

Kelly, J. (2007). Making client values explicit in value management workshops. Construction Management and Economics, 25(4), pp.435-442.

Kelly, J. and Male, S. (2006). Best value in construction. 1st ed. Blackwell publishing. Kelly, J. and Male, S. (2008). A re-appraisal of value methodologies in construction. Kelly, J., Male, S. and Graham, D. (2004). Value Management of Construction Projects. Kirkham, R. (2007). Ferry and Brandon's cost planning of buildings. 8th ed. Oxford: Blackwell publishing.

Kumar, K. and van Dissel, H. (1996). Sustainable Collaboration: Managing Conflict and Cooperation in Interorganizational Systems. MIS Quarterly, 20(3), p.279.

Leung, M. and Liu, A. (2003). Analysis of value and project goal specificity in value management. Construction Management and Economics, 21(1), pp.11-19. 
Leung, M., Ng, S. and Cheung, S. (2002). Improving Satisfaction through Conflict Stimulation and Resolution in Value Management in Construction Projects. Journal of Management in Engineering, 18(2), pp.68-75.

Lin, G. and Shen, Q. (2007). Measuring the Performance of Value Management Studies in Construction: Critical Review. Journal of Management in Engineering, 23(1), pp.2-9.

Locke, M. (1994). Management of value in the British construction industry.

Mack, L. (2010). The philosophical underpinnings of educational research.

Male, S. and Kelly, J. (1990). The economic management of construction projects. Habitat International, 14(2-3), pp.73-81.

Male, S., Gronqvist, J., Bowles, G. and Fernie, S. (1999). The professional standing of value management: a global study of legislation, standards, certification, and institutions.

Marzouk, M. (2011). ELECTRE III model for value engineering applications. Automation in Construction, 20(5), pp.596-600.

Newman, C., Edwards, D.J., Martek, I., Lai, J. and Thwala, W.D. (2020) Industry 4.0 Deployment in the Construction Industry: A Bibliometric Literature Review and UKbased Case Study, Smart and Sustainable Built Environment DOI: https://doi.org/10.1108/SASBE-02-2020-0016

Michalski, G. (2008). Corporate inventory management with value maximization in view. Agricultural Economics (Zemédělská ekonomika), 54(No. 5), pp.187-192.

Nkado, R. and Meyer, T. (2001). Competencies of professional quantity surveyors: A South African perspective. Construction Management and Economics, 19(5), pp.481-491.

Norton, B. and MacElligott, W. (1995). Value management in construction. London: Macmillan.

Oke, A., Ogunsemi, D. and Adeyelu, M. (2017). Quantity surveyors and skills required for procurement management. International Journal of Construction Management, 18(6), pp.507-516.

Oki, A. (2010). Assessment of the Perceived Competencies of Nigerian Quantity Surveyors as Value Managers.

Olanrewaju, A. and Anahve, P. (2015). Duties and Responsibilities of Quantity Surveyors in the Procurement of Building Services Engineering. Procedia Engineering, 123, pp.352360.

Olawumi, T., Akinrata, E. and Arijeloye, B. (2016). Value Management - Creating Functional Value for Construction Project: An Exploratory Study. 
Oliver, P. (2010). A Student's Guide to Strengthening an Online Community. TechTrends, 54(5), pp.69-75.

Oluwasuji Dada, J. (2014). A Principal Component Analysis of Skills and Competencies Required of Quantity Surveyors: Nigerian Perspective. Organization, technology and management in construction: An international journal, 6(2).

Othman, A., Hassan, T. and Pasquire, C. (2004). Drivers for dynamic brief development in construction. Engineering, Construction and Architectural Management, 11(4), pp.248258.

Parfitt, M. and Sanvido, V. (1994). Closure to " Checklist of Critical Success Factors for Building Projects” by M. K. Parfitt and V. E. Sanvido (July, 1993, Vol. 9, No. 3). Journal of Management in Engineering, 10(5), pp.64-64.

Pärn, E. A., Edwards, D. J. and Sing, M. C. P. (2018) Origins and probabilities of MEP and structural design clashes within a federated BIM model. Automation in Construction, 85, pp. 209-219. DOI: https://doi.org/10.1016/j.autcon.2017.09.010

Pärn, E. A. and Edwards, D. J. (2019) Cyber threats confronting the digital built environment: Common data environment vulnerabilities and block chain deterrence, Engineering, Construction and Architectural Management, DOI: https://doi.org/10.1108/ECAM-03$\underline{2018-0101}$

Petrash, G. (1996). Dow's journey to a knowledge value management culture. European Management Journal, 14(4), pp.365-373.

Pham, L. (2018). QUALITATIVE APPROACH TO RESEARCH A review of advantages and disadvantages of three paradigms: positivism, interpretivism and critical inquir.

Poudyal, C. (2013). Private Schooling and Fayol's Principles of Management: A Case from Nepal. Journal of Education and Research, 3, pp.6-23.

Rics.org. (2019). Value Management and Value Engineering, 1st edition. [online] Available at: https://www.rics.org/uk/upholding-professional-standards/sectorstandards/construction/black-book/value-management-and-value-engineering-1st-edition/ [Accessed 2 Dec. 2019].

Roberts, C. J., Edwards, D. J., Hosseini, M. Reza., Matzeo-Garcia, M. and Owusu-Man, D. (2019) Post occupancy evaluation: a critical review of literature. Engineering, Construction and Architectural Management. 26(9), pp. 2084-2106. DOI: https://doi.org/10.1108/ECAM-09-2018-0390

Seeley, I. (1984). Quantity Surveying Practice. 2nd ed. London. 
Shen, Q. and Liu, G. (2007). The Selection of Benchmarking Partners for Value Management: An Analytic Approach. International Journal of Construction Management, 7(2), pp.1122.

Sik-wah Fong, P., Shen, Q. and Cheng, E. (2001). A framework for benchmarking the value management process. Benchmarking: An International Journal, 8(4), pp.306-316.

Soiferman, K. (2010). Compare and Contrast Inductive and Deductive Research Approaches.

Stuart, G. and Anita, G. (2007). Theory and practice in value management: a reply to Ellis et al (2005). Construction Management and Economics.

Thomson, D., Austin, S., Devine-Wright, H. and Mills, G. (2003). Managing value and quality in design. Building Research \& Information, 31(5), pp.334-345.

Thyssen, M., Emmitt, S., Bonke, S. and Kirk-Christoffersen, A. (2010). Facilitating Client Value Creation in the Conceptual Design Phase of Construction Projects: A Workshop Approach. Architectural Engineering and Design Management, 6(1), pp.18-30.

Zainul Abidin, N. and Pasquire, C. (2005). Delivering sustainability through value management. Engineering, Construction and Architectural Management, 12(2), pp.168180.

Zimina, D., Ballard, G. and Pasquire, C. (2012). Target value design: using collaboration and a lean approach to reduce construction cost. Construction Management and Economics, 30(5), pp.383-398. 
Table 1 - Comparison Between Value Management and Value Engineering

\begin{tabular}{|c|c|c|c|c|c|c|c|}
\hline Concept & Definitions & Emphasis & Citations & \multirow{6}{*}{$\begin{array}{l}\text { Concept } \\
\text { Value } \\
\text { Engineering }\end{array}$} & \multirow[b]{2}{*}{$\begin{array}{l}\text { Definitions } \\
\text { A service that synthesises } \\
\text { traditional quantity surveying } \\
\text { skills with structured cost } \\
\text { reduction or substitution } \\
\text { techniques using a multi- } \\
\text { disciplinary team }\end{array}$} & \multirow{2}{*}{$\begin{array}{l}\text { Emphasis } \\
\text { A structured team- } \\
\text { based cost } \\
\text { reduction exercise }\end{array}$} & \multirow{2}{*}{$\begin{array}{l}\text { Citations } \\
\text { (Rangelova and } \\
\text { Traykova, 2014) }\end{array}$} \\
\hline \multirow[t]{5}{*}{$\begin{array}{l}\text { Value } \\
\text { Management }\end{array}$} & $\begin{array}{l}\text { The aim is to procure the project } \\
\text { through minimal use of function } \\
\text { offering high function in return. }\end{array}$ & $\begin{array}{l}\text { Cost based } \\
\text { exercise }\end{array}$ & $\begin{array}{l}\text { United States } \\
\text { Defense } \\
\text { Department } \\
(2011)\end{array}$ & & & & \\
\hline & $\begin{array}{l}\text { Value Management should not } \\
\text { be solely based on reducing } \\
\text { project costs and should instead } \\
\text { focus on working systematically } \\
\text { in a multidisciplinary effort } \\
\text { to enhance the value of a } \\
\text { construction project. }\end{array}$ & $\begin{array}{l}\text { Team based } \\
\text { approach }\end{array}$ & $\begin{array}{l}\text { (Rangelova and } \\
\text { Traykova, } 2014\end{array}$ & & $\begin{array}{l}\text { Elimination of unnecessary } \\
\text { project cost }\end{array}$ & $\begin{array}{l}\text { Focuses on } \\
\text { unnecessary project } \\
\text { costs }\end{array}$ & (RICS, 2017) \\
\hline & $\begin{array}{l}\text { The value management } \\
\text { identifies and removes } \\
\text { unnecessary risks. }\end{array}$ & $\begin{array}{l}\text { Identifying } \\
\text { risk }\end{array}$ & $\begin{array}{l}\text { (Abidin and } \\
\text { Pasquire, 2005) }\end{array}$ & & $\begin{array}{l}\text { Organised approach to the } \\
\text { provision of necessary } \\
\text { functions at the lowest cost }\end{array}$ & $\begin{array}{l}\text { Targets the lowest } \\
\text { cost options }\end{array}$ & $\begin{array}{l}\text { (Kelly and } \\
\text { Male, 1993) }\end{array}$ \\
\hline & $\begin{array}{l}\text { The idea is to review the value } \\
\text { of the project holistically and } \\
\text { not to draw down on specific } \\
\text { details }\end{array}$ & $\begin{array}{l}\text { Understandi } \\
\text { ng that VM } \\
\text { is a total } \\
\text { process }\end{array}$ & $\begin{array}{l}\text { (Kelly et al., } \\
\text { 2014) }\end{array}$ & & $\begin{array}{l}\text { VE programs are implemented } \\
\text { to enhance the value received } \\
\text { over the life cycle of } \\
\text { constructed assets }\end{array}$ & Life cycle costs & $\begin{array}{l}\text { (Marzouk, } \\
\text { 2011) }\end{array}$ \\
\hline & $\begin{array}{l}\text { A structured functional analysis } \\
\text { and other problem-solving tools } \\
\text { and techniques in order to } \\
\text { determine explicitly a client's } \\
\text { needs and want }\end{array}$ & $\begin{array}{l}\text { Identifying } \\
\text { the problems } \\
\text { drivers } \\
\text { within the } \\
\text { project }\end{array}$ & (Kelly 1993) & & $\begin{array}{l}\text { The philosophy of value } \\
\text { engineering looks towards } \\
\text { reducing cost without } \\
\text { sacrificing quality }\end{array}$ & $\begin{array}{l}\text { Reducing costs } \\
\text { without reducing } \\
\text { quality }\end{array}$ & $\begin{array}{l}\text { (Kelly et al., } \\
\text { 2014) }\end{array}$ \\
\hline
\end{tabular}


Figure 1 - The Role of a Quantity Surveyor

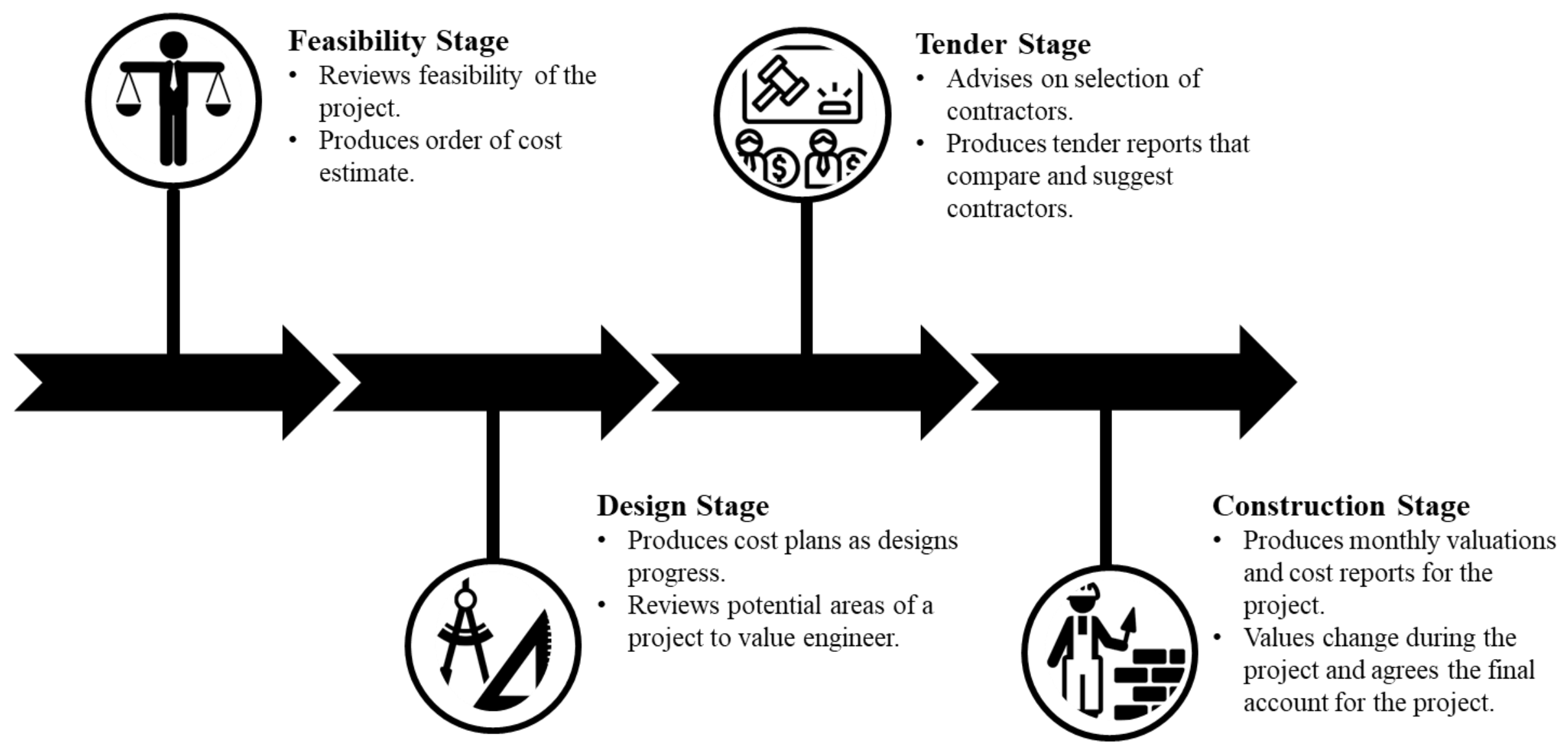


Figure 2 - Results from Voyant Tools analysis software relating to the question As a minimum, what content should be covered in the 'Information Workshop'?

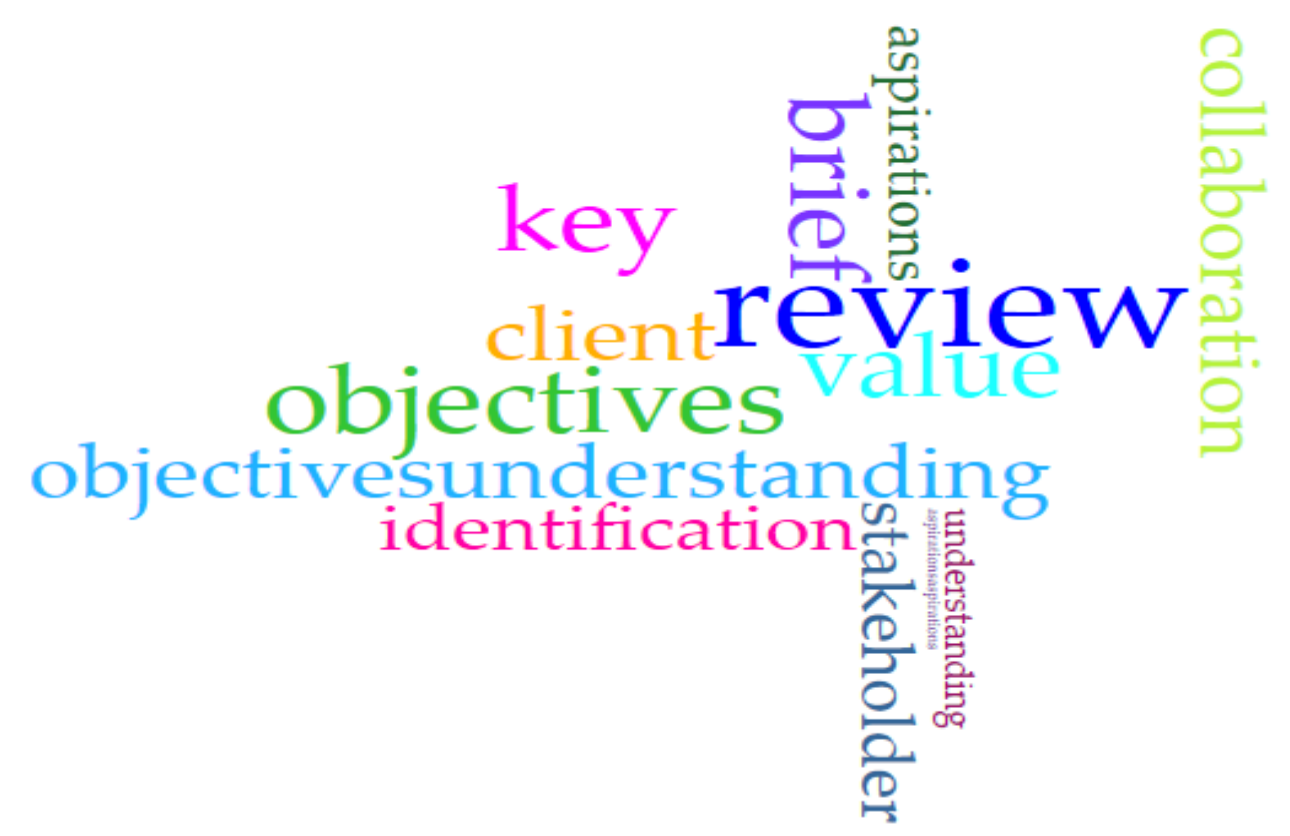


Figure 3 - Results from Voyant Tools analysis software relating to the question 'From experience, what are the roles and responsibilities of the Quantity Surveyor in the 'Evaluative Workshop'?

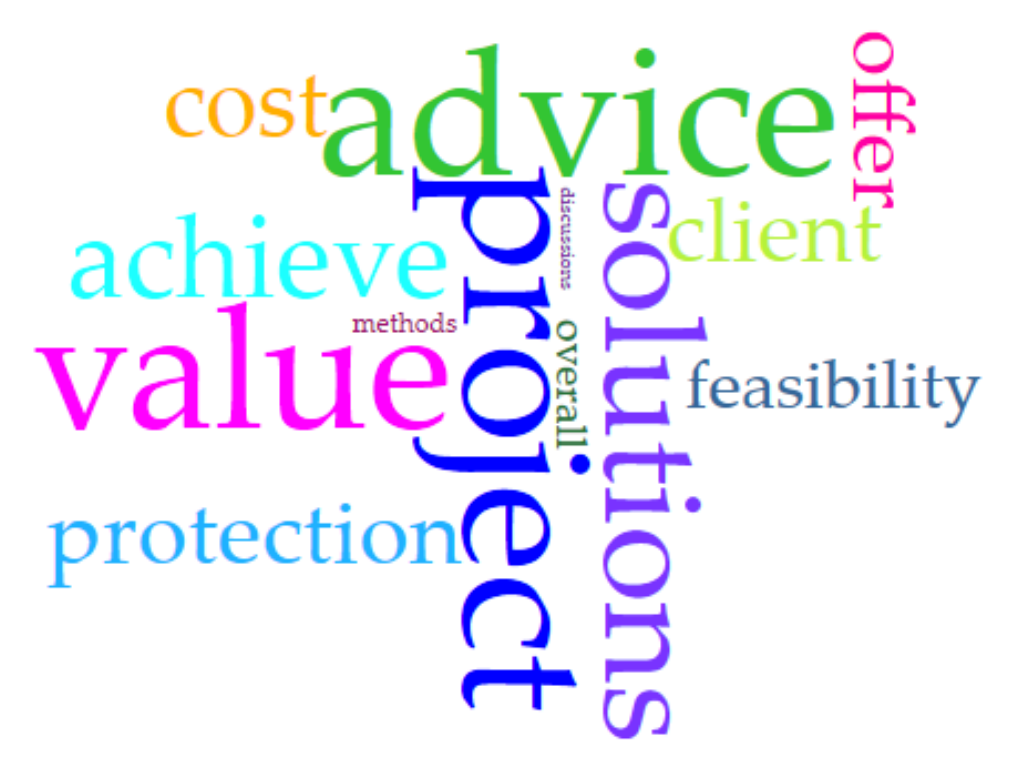


Table 2 - Traditional workshop content

\begin{tabular}{|c|c|c|}
\hline $\begin{array}{l}\text { Workshop } \\
\text { element }\end{array}$ & Themes & Content \\
\hline 1 & $\begin{array}{l}\text { The } \\
\text { information } \\
\text { workshop }\end{array}$ & $\begin{array}{ll}\text { - } & \text { Understanding the project aspirations; } \\
\text { - } & \text { Understand the main project goal; and } \\
\text { - } & \text { Review of design and project specifications by the team. }\end{array}$ \\
\hline 2 & $\begin{array}{l}\text { The creativity } \\
\text { workshop }\end{array}$ & $\begin{array}{l}\text { Encourages members to brainstorm new innovative ideas which could replace } \\
\text { older ideas; } \\
\text { - Encourages positive ideas in a positive environment; and } \\
\text { Encourages collaboration between project members. }\end{array}$ \\
\hline 3 & $\begin{array}{l}\text { The evaluative } \\
\text { workshop }\end{array}$ & $\begin{array}{l}\text { - The team work together to assess the best options to improve the projects value; } \\
\text { - } \quad \text { Assess the criteria and advantages and disadvantages of each project option; and } \\
\text { - Assess detail such as time, cost, flexibility and function of each project option. }\end{array}$ \\
\hline 4 & $\begin{array}{l}\text { The } \\
\text { development } \\
\text { workshop }\end{array}$ & $\begin{array}{l}\text { - The team develop the chosen option from workshop 3; } \\
\text { - Detailed economical study of the option; and } \\
\text { Details proposals and descriptions of the chosen option must be drawn up to } \\
\text { ensure all members understand the option. }\end{array}$ \\
\hline 5 & $\begin{array}{l}\text { The } \\
\text { presentation } \\
\text { workshop }\end{array}$ & $\begin{array}{l}\text { Each discipline presents their proposals that they have worked up for the option } \\
\text { e.g. The Quantity Surveyor provides the cost for the option or the Architect } \\
\text { provides the drawings for the option. This can be presented visually in front of the } \\
\text { team through a PowerPoint presentation explaining how the option discussed is } \\
\text { the one that will bring the best value. }\end{array}$ \\
\hline 6 & $\begin{array}{l}\text { The feedback } \\
\text { workshop }\end{array}$ & $\begin{array}{l}\text { - Value management leader reports on results obtained from the study } \\
\text { - } \quad \text { Assessment of lessons learnt from the study } \\
\text { - Consideration of proposals that can be used to improve the option for the future. }\end{array}$ \\
\hline
\end{tabular}

Sources: Ellis (2004); Kelly (2004); Thomas (2005); and Stewart (2010). 
Table 3 - Hybrid workshop content including the roles and responsibilities of the Quantity Surveyor

\begin{tabular}{|c|c|c|c|c|}
\hline $\begin{array}{l}\text { Work } \\
\text { shop } \\
\text { element }\end{array}$ & Themes & Content & Description about workshop & $\begin{array}{l}\text { Roles and responsibilites of the Quantity } \\
\text { Surveyor }\end{array}$ \\
\hline 1 & $\begin{array}{l}\text { The } \\
\text { information } \\
\text { workshop }\end{array}$ & $\begin{array}{l}\text { - Briefing on the client; } \\
\text { Identification of key client/stakeholder } \\
\text { objectives; } \\
\text { Defining the term 'value' and understanding } \\
\text { what the client/stakeholder's perceive value to } \\
\text { be; and } \\
\text { - Understanding how the aspirations of the } \\
\text { client/stakeholder will create value to the } \\
\text { project. }\end{array}$ & $\begin{array}{l}\text { - The workshop would last between } 2-4 \\
\text { hours. } \\
\text { It is considered the most important } \\
\text { workshop out of them all; } \\
\text { It gives the oppurtunity for the project } \\
\text { team to meet one another, for some it will } \\
\text { be the first time meeting; The session gives } \\
\text { the client/stakeholder the oppurtunity to } \\
\text { voice how he wants to see value achieved } \\
\text { in the project. }\end{array}$ & $\begin{array}{l}\text { - Identification of the key drivers from the } \\
\text { client/stakeholder in relation to costs. } \\
\text { To be proactive in ensuring that the } \\
\text { client/stakeholders' key objectives are } \\
\text { reasonable and feasible. } \\
\text { To ensure the client is protected when } \\
\text { assessing costs and value related to the } \\
\text { project. }\end{array}$ \\
\hline 2 & $\begin{array}{l}\text { The } \\
\text { creativity } \\
\text { workshop }\end{array}$ & $\begin{array}{l}\text { - To collaborate and interact as a project team and } \\
\text { assess the best possible methods to achieve } \\
\text { overall project value; } \\
\text { To be proactive in ensuring that the } \\
\text { client/stakeholders, key objectives are } \\
\text { reasonable and feasible; and } \\
\text { - Encourages positivity in a positive environment } \\
\text { that can lead to creativity among workshop } \\
\text { members. } \\
\text { To collaborate with key subcontractors and } \\
\text { suppliers to ensure the best quality materials are } \\
\text { provided; }\end{array}$ & $\begin{array}{l}\text { - The workshop would last between } 2-4 \\
\text { hours. } \\
\text { It offers the oppurtinity for engagement } \\
\text { between the VM team. } \\
\text { It offers the chance for materials/goods to } \\
\text { be visibly presented to the team for the } \\
\text { first time. }\end{array}$ & $\begin{array}{l}\text { - To continue to assess the best possible } \\
\text { methods to achieve overall project value. } \\
\text { Understanding how the aspirations of the } \\
\text { client/stakeholder will create value to the } \\
\text { project. } \\
\text { To ensure the client is protected when } \\
\text { assessing costs and value related to the } \\
\text { project. }\end{array}$ \\
\hline 3 & $\begin{array}{l}\text { The } \\
\text { evaluative } \\
\text { workshop }\end{array}$ & $\begin{array}{l}\text { - Review of the key client/stakeholder aims and } \\
\text { objectives that had been established in } \\
\text { workshops } 1 \text { and } 2 \text {. } \\
\text { - Review any contraints related to time, cost, } \\
\text { quality and programme that may directly affect } \\
\text { the client/stakeholders original objectives. } \\
\text { To consider why original aims and objectives } \\
\text { are not feasible. } \\
\text { To acknowledge the project budget and assess } \\
\text { whether original client/stakeholder aims, and } \\
\text { objectives are feasible. } \\
\text { - Agree on methods going forward to progress the }\end{array}$ & $\begin{array}{l}\text { - The workshop would last between } 2-4 \\
\text { hours. } \\
\text { It gives the oppurtunity to discuss as a } \\
\text { team the progress of the project so far. } \\
\text { It allows the oppurtunity for members to } \\
\text { give suggestions on how project specifics } \\
\text { could be improved in order to progress } \\
\text { forward. }\end{array}$ & $\begin{array}{l}\text { - Discuss as a project team if members } \\
\text { believe client aspirations are not } \\
\text { feasible or offer project value. } \\
\text { Offer cost advice relating to other } \\
\text { methods/solutions that could help to } \\
\text { client achieve overall project value. } \\
\text { To ensure the client is protected when } \\
\text { assessing costs and value related to the } \\
\text { project. }\end{array}$ \\
\hline
\end{tabular}


project.

- To review members of the supply chain to ensure they share the same project goals and vision.

4 The

development workshop

- Following on from workshop 3, the value management team progress the agreed options from the previous workshop

- To review any change from the original scope. Assess how this affects the project moving forward and progress on the agreed scope.

- To continue to drive and deliver overall project value as a team at every oppurtunity.

The

presentation workshop

The

feedback

workshop
- $\quad$ Each discipline presents their proposals that they have worked up for the option e.g. The Quantity Surveyor provides the cost for the option or the Architect provides the design proposal for the project. This can be presented visually in front of the team through a PowerPoint presentation explaining how the option discussed is the one that will bring the best value.

- Materials specification and quality of construction are featured heavily.

- The roles of key suply chainsubcontractors and supply chain partners are discussed and evaluated.

- The value management leader reports on results obtained from whereby all value management team members meet to discuss and assess the advantages and disadvantages of the study that has been carried out.

- Consideration of proposals that can be used to improve the workshop process going forward.

- Further discusisons with the client are held to ensure good communication is preserved.
- The workshop would last between 2-4. hours.

- To work together on the agreed scope in order to maintain value throughout the project.

The workshop would last between 2-4 hours.

Each discipline has the oppurtunity to present their work that they have been working on throughout the workshop process.

- It offers the chance for the final version of the materials/goods to be visibly presented to theteam.. The

It gives the oppurtunity for open discussions to be held on the overall workshop process with acknowledgemen to lessons learnt/oppurtunities for future improvement.
To value any change from the original scope. Assess how this will affect and benefit the project moving forward.

To maintain a strong position that the role of the quantity surveyor is to drive overal project value, and not to cut the project costs.

- To ensure the client is protected when assessing costs and value related to the project.

To present the cost plan to all of the value management workshop team.

To ensure all memebers in the workshop understand how you have arrived at the finalised cost for the project.

- To ensure that you state where you driven best project value where possible.

To acknowledge feedback from the value management leader.

To also offer any feedback to the value management leader on how the process could be progressed in the future.

To ensure all of the relationships within the workshop team are maintained for future working oppurtunities. 


\section{APPENDIX A - FOCUS GROUP QUESTIONS}

\section{Question Value Management Workshop Questionnaire}

No.

$1 \quad$ How long should each workshop last?

2 As a minimum, what content should be covered in the 'Information Workshop'?

3 As a minimum, what content should be covered in the 'Creativity Workshop'?

$4 \quad$ As a minimum, what content should be covered in the 'Evaluative Workshop'?

5 As a minimum, what content should be covered in the 'Development Workshop'?

6 As a minimum, what content should be covered in the 'Presentation Workshop'?

$7 \quad$ As a minimum, what content should be covered in the 'Feedback Workshop'?

8 Do you think that worked examples relating to the curriculum discussed should be given in the workshops?

9 From experience, what are the roles and responsibilities of the Quantity Surveyor in the 'Information Workshop'?

10 From experience, what are the roles and responsibilities of the Quantity Surveyor in the 'Creativity Workshop'?

11 From experience, what are the roles and responsibilities of the Quantity Surveyor in the 'Evaluative Workshop'?

12 From experience, what are the roles and responsibilities of the Quantity Surveyor in the 'Development Workshop'?

13 From experience, what are the roles and responsibilities of the Quantity Surveyor in the 'Presentation Workshop'?

14 From experience, what are the roles and responsibilities of the Quantity Surveyor in the 'Feedback Workshop'? 